\title{
Evaluation of financial statements of sports clubs for 2019 and 2020 operational periods in terms of the covid-19 pandemic and research in terms of financial risk
}

\author{
Adnan Sevim \\ a Anadolu University, Faculty of Economics and Administrative Sciences, Department of Business Administration, \\ Accounting and Finance Department, asevim@anadolu.edu.tr, Research Article, https://orcid.org/0000-0002-0864- \\ $3719^{b}$ Add
}

\begin{abstract}
A B S T R A C T
The Covid-19 pandemic and the accompanying uncertainties deeply affected the activities and financial structures of businesses and caused negative effects on their financial statements in many respects. Sports clubs are at the top of the list of businesses that suffer the most from the negativities of the pandemic process and experience a lot of loss in their financial and operational activities. Considering the developments both in Europe and in the World, the temporary postponement of sports matches, the start of competitions without spectators, the restructuring of club debts have seriously affected sports clubs, which are currently experiencing economic difficulties, deteriorate their liquidity, cash flows and increase uncertainty by making debt payments difficult. In addition, as the impact of risks on future performance increases, risk management practices have gained importance. In this context, information on the current ratio, cash ratio, financial leverage ratio, financing ratio, debt / equity ratio, and financial risk ratio obtained from the financial statement data for the period of 2019 and 2020 were used to evaluate the financial risk levels of 12 sports clubs. The deterioration in the financial structures of the sports clubs most affected by the pandemic process was examined and the risks encountered were discussed. In addition, the comparative financial analysis results were evaluated by analysing the effect of the financial structure and financial reporting of the clubs.
\end{abstract}

\author{
A R T I C L E I N F O \\ Keywords: \\ Risk, Liquidity, Financial Reporting, \\ Financial Analysis, Fair Play, \\ Football Clubs, European Football \\ Leagues, TFF, UEFA, FIFA \\ *Corresponding author: \\ asevim@anadolu.edu.tr \\ Prof. Dr. Adnan Sevim \\ Article history: \\ Received 17-01-2021 \\ Revised 11-04-2021 \\ Accepted 06-05-2021 \\ DOI:https://doi.org/10.51410/jcgirm.8.1.8
}

\section{INTRODUCTION}

The COVID-19 epidemic, which started in the People's Republic of China and spread all over the world, deeply affects and transforms our daily life. The World Health Organization's announcement of the virus to the world on January 30, 2020 and its subsequent acceptance of the virus as a pandemic on March 11, 2020 are important turning points that transform our lives from our individual life to our social life. The measures taken against the epidemic and preventive measures against the epidemic, both in the world and in Turkey, primarily affected human behaviour and this situation has changed the consumption habits, social 
relations and economic preferences in daily life. It has been inevitable that the economic, social, cultural and technological developments caused by the epidemic negatively affect the businesses and their activities. These negative developments manifest themselves as uncertainty in the markets, disruptions in supply chains, interruptions, production delays, fluctuations in demand, and decrease in sales and productivity.

Sports clubs are at the top of the businesses most affected by the COVID-19 outbreak. Competitions postponed due to the epidemic, unsuccessful sports activities caused sports clubs to be deprived of their most basic sources of income. This situation has revealed significant uncertainties in the cash management, continuity, operating processes, contracts and estimations of the clubs and influenced them to change their strategies. In this context, financial reports, which reveal the activity results, financial status, cash management and economic performance of sports clubs, reflect the complex, uncertain and difficult to forecast period of the new period, as in all economic activities, in the process that develops with the pandemic declaration. Therefore, the significant uncertainties created by the negative effects of COVID-19 in the economic order and in the financial reporting processes and systems of sports clubs reveal this new reality, as well as serious concerns about the continuity in the future.

\section{COVID-19 PANDEMIC PROCESS}

The environment of uncertainty created by the COVID-19 pandemic continues to affect business activities and processes in many ways, since such an event has not been encountered before and it is different from the crises experienced in the past. Since changes in people's consumption and purchasing behaviour affect their economic preferences, the deterioration in expected cash flows in the short term also disrupts the general structure of business activities in the long run. In addition, since it is not known when the pandemic will end and life will return to normal, the disruptions and delays in the raw material, supply chain, production, sales and distribution channels in the economic cycle increase the uncertainty in the process. Consequently, the adversities originating from Covid-19 disrupt the market order, cause fluctuations in supply and demand, and businesses that shut down with a decrease in productivity cause both customer and employment loss. However, the deterioration in international markets and the sharp declines in the stock markets cause stagnation of investments, failure to fulfill contractual obligations, increase in 
unemployment, proliferation of bankruptcies and suppression of the financial system (McKinsey and Company, 2020).

Economic fluctuations caused by the Covid-19 pandemic pose significant risks in sustaining business activities. The pandemic effects can cause even the most basic activities to fail, as businesses are established on a continuity basis, have an indefinite life, and their financial statements are arranged in accordance with the principle of continuity of the business. This situation, when we consider the experienced conditions and events together, is effective in explaining the lack of suitable environment for activities, the existence of serious doubts about continuity and the uncertainties caused by these events and conditions in the footnotes of the financial statements (AASB, 2020; Mazars, 2020). Disclosures, action plans and supplementary additional information on this subject should include the effects of significant uncertainties and the judgments and evaluations made by the business management against them (Adana and Özbirecikli, 2020). In addition, comprehensive evaluations should be made in the footnotes regarding the changes in the previous periods that affect the current period and how the liquidity risk is evaluated, the nature of the risk assessment procedures and the responses to these risks and their effects on the financial statements (BDS, 570: 10-11). In this context, important evaluations and decisions to be made regarding the continuity of uncertainty conditions will contribute to the understanding of the financial situation and performance and to the access of all stakeholders to the financial information they need.

\section{EFFECTS OF COVID-19 PANDEMIC ON SPORTS CLUBS}

Although the preventive measures, restrictions and policies that came with the Covid-19 pandemic affected the activities of many businesses, they affected sports clubs more and more directly, and brought club activities to a halt. Quarantines imposed by public authorities, calls to stay away from crowded environments and prohibitions for gathering have seriously affected and put pressure on sports clubs operating with large-scale participation, and as a result of these decisions, the revenues of the clubs have suddenly decreased. Despite the continuation of contractual obligations, the liquidity and cash flow problems caused by the decrease in revenues and the resulting losses caused the clubs to be in a difficult situation in addition to increasing their capital requirements (Deloitte, 2020). Therefore, sports clubs whose cash flows have deteriorated, cannot make a profit and are faced with insufficient cash have produced solutions with measures to reduce existing expenditures, control costs, restructure short-term liabilities and do not spend unnecessarily, 
in order to keep their businesses alive, with the least damage from this process. They sought ways out (ICAEW, 2020).

Postponements and cancellations that directly affect sports clubs cause the removal of important income sources such as broadcasting, sponsorship, advertising and matchday revenues, as well as affecting the sports activities of the clubs. In addition to these, the inability to organize international tournaments combined with the economic and social problems brought by Covid-19, sports clubs in Europe have been deprived of the expected income. Considering the fact that approximately $80 \%$ of the sponsorship and broadcasting revenues of the tournaments held by UEFA are shared with the federations of the participating countries, the level of the versatile losses of sports clubs is better understood when the revenues of the teams from the competitions that will result in victory and tie. Considering the fact that professional and amateur sports activities in the sports industry are deprived of these important sources of income will leave them with many problems to continue their activities, it has become inevitable that the losses and possible damages that may be experienced will be at record levels (Akkaş, 2020; Gough, 2020).

Sports clubs find themselves in the production of goods and services by establishing economic enterprises in order to increase their income other than sports activities and to create new sources of income. These income items, which are established in order to diversify the sources of income and to generate income by making the best use of sports activities; Stadium revenues consist of facility and rental revenues, and sales revenues of products with logos or licenses. In the process that started with the postponement and cancellation of the competitions in the Covid-19 pandemic, these economic activities were also affected, and many facilities and stores stopped their activities within the scope of quarantine measures. The table showing the estimated revenue losses of the affected European Football Leagues in the 2019-2020 season is as follows:

Table 1: Estimated income losses of european leagues (million euros)

\begin{tabular}{|l|c|c|c|}
\hline \multicolumn{1}{|c|}{ Country } & Matchday revenues & Broadcasting revenue & Trade revenues \\
\hline England & 180 & 800 & 300 \\
\hline Spain & 170 & 600 & 200 \\
\hline Germany & 140 & 400 & 250 \\
\hline Italy & 100 & 450 & 150 \\
\hline
\end{tabular}




\begin{tabular}{|l|l|l|l|}
\hline France & 60 & 200 & 140 \\
\hline
\end{tabular}

Source: (Lange, 2020)

While the contractual obligations of sports clubs continue, failure to hold the matches will primarily affect the ticket revenues on the day of the match and there will be a financial loss in important income sources that is difficult to foresee, as advertising and sponsorship revenues will not be obtained in an environment without spectators. In addition, the continuation of the administrative activities of the club causes serious problems in fulfilling its financial obligations, making contractual wage payments to athletes and paying debts to financial institutions. Therefore, in the current structure, related party problems between the association and the company, inadequate use of resources, accumulated losses from previous years, loss of capital and being in debt cause club revenues to be unable to meet its expenses. In this case, when the difficulties in fulfilling the financial obligations and the problems in meeting the UEFA Fair Play Criteria combined with the Covid-19 pandemic, the existing problems became more unbearable, deeply shaking the continuity of the clubs and moving away from the sustainable structure. In terms of forming the subject of the study, the mentioned risks and their effects will be examined in the following title.

\section{ASSESSMENT OF RISKS AND RISKS}

Risk refers to the possibility of an undesirable situation occurring and expresses uncertainty. When the financial structures of football clubs are analysed it is seen that they are more affected by financial risk and exchange rate risk. Financial risk is an unsystematic risk and it is possible for businesses to control themselves. Especially companies that want to take advantage of the leverage effect of debt borrow high amounts (Ercan and Ban, 2012). Therefore, depending on the change in debt amount, the level of risk incurred varies for each enterprise (Aksoy and Tanrı̈ven, 2007). Risk, which is defined as a positive or negative return, depending on financially future alternatives, or as a positive or negative difference between actual value and expected value, is generally the possibility of encountering unexpected consequences arising from uncertainties about future events. On the other hand, risk is the measurable part of uncertainty, and if the probability estimation for the future is made objectively, risk is called uncertainty if it is done subjectively (Usta, 2012).

Financial risks faced by businesses; It is possible to group them under four headings as market risk, liquidity risk, credit risk and operational risks. Market risk of these; It is the 
possibility of financial loss arising from unexpected changes in exchange rate, interest rate, security and product prices (Bolak, 2004). This risk constitutes an important part of the financial risks faced by businesses in both financial and non-financial sectors. Liquidity risk also appears as a funding risk and can be defined as the inability to provide the needed funds on time and at the desired cost or the inability to dispose of the assets at the desired time and price. Credit risk, on the other hand, can also be named as counterparty risk, and it arises from the failure of the person or institution with whom the company has financial transactions to fulfil its obligations. Operational risk arises from irregularities and insufficiencies in transaction processes or management. Operational risk is related to personal errors, systemic errors, inadequate controls and procedures (Ercan and Ban, 2012).

With risk management practices, eliminating negative risks, reducing their negative effects or making them create opportunities for the business; It becomes possible to evaluate the opportunities by increasing the probability of realization or the effects of positive risks. It is not enough to carry out risk management studies alone, and these studies should also be disclosed to the public. In this way, it will be possible for information users outside the company to take into account the risks of the relevant businesses and the work related to the management of these risks, and take these factors into account while making decisions. Therefore, risk management is a process that starts with steps in the form of identifying, evaluating, and managing risks, and in short, businesses identify their own risks and respond to them in a beneficial way. Since it is not a static but a dynamic process, the risk management process continues with controls and improvement studies after the implementation of the prepared plan. For this reason, it is necessary to make continuous reviews and to monitor the up-to-dateness and effectiveness of the risks identified and the counter steps taken.

\section{THE METHODOLOGY OF THE RESEARCH AND THE RESULTS}

In this part of the study, regarding the information obtained from the financial reports of 2019 and 2020 of the sports clubs from France, Italy, Germany, England, Turkey and Spain, which are the most affected by the Covid-19 pandemic; In addition to explanations about the purpose, importance and scope of the research, the method of data collection and the analysis process of the obtained information will be included. 


\subsection{The Purpose and importance of the research}

The level of impact of the Covid-19 pandemic on football clubs and the risks they face can be understood from the amounts expressed in the financial reports and their explanatory footnotes. The fact that sports clubs use a special fiscal period and the end date in the financial statements is May 31, provides very useful information in terms of seeing these effects and makes it easier to see the pandemic effect. Since the acceptance of the Covid-19 pandemic as a pandemic on March 11, 2020 and the subsequent taking of preventive measures directly affect the normal activities of football clubs during the season, pandemic problems can be seen easily from these reports. In this context, in this heading of the study, first of all, financial information of four major football clubs in Turkey in the 2019/2020 Spor Toto Super League Cemil Usta season were reached. In addition, 8 big football clubs, whose financial reports were published France, Italy, Germany, England and Spain (FIGES), were added, and the independent audit reports and annual reports of 12 football clubs for 2019 and 2020 were reached. Based on this information obtained, financial information regarding the pre and post pandemic was collected, the effects it created on the financial structure and the differences in reporting were analyzed. The collection and analysis of all this information includes critical information in terms of seeing the first impact of the Covid19 pandemic on financial reports and tracing these effects, and it is also important in terms of being a source for the work to be done.

\subsection{Scope and method of the research}

The financial reports of the football clubs to be examined for research purposes have been obtained from the Public Disclosure Platform (PDP-KAP) in Turkey and from the investor relations section on the websites of the relevant enterprises. Financial reports of football clubs of FIGES, on the other hand, were accessed from each club's own website, and in some cases, access was made to the reports from common platforms disclosed to the public. In this context, with the addition of clubs in various countries, 4 of which are in Turkey, the financial reports of a total of 12 football clubs, which are listed in the table below and whose reports have just been published, were analyzed by content analysis method, the data were systematically gathered and financial information were summarized. In addition, summary information collected within the scope of the study were evaluated with financial analysis methods, inferences were made regarding the results obtained, and predictions for the future were also included with explanations of Covid-19. 
Table 2. List of sports clubs and reports examined within the scope of the research

\begin{tabular}{|c|l|l|c|c|}
\hline Number & \multicolumn{1}{|c|}{ Country } & \multicolumn{1}{|c|}{ Sport club } & Report Date & Report Date \\
\hline 1 & Turkey & Beşiktaş & 31 May 2019 & 31 May 2020 \\
\hline 2 & Turkey & Fenerbahçe & 31 May 2019 & 31 May 2020 \\
\hline 3 & Turkey & Galatasaray & 31 May 2019 & 31 May 2020 \\
\hline 4 & Turkey & Trabzonspor & 31 May 2019 & 31 May 2020 \\
\hline 5 & England & Manchester United & 30 June 2019 & 30 June 2020 \\
\hline 6 & England & Celtic & 30 June 2019 & 30 June 2020 \\
\hline 7 & England & Everton & 30 June 2019 & 30 June 2020 \\
\hline 8 & England & Rangers & 30 June 2019 & 30 June 2020 \\
\hline 9 & Italy & Juventus & 30 June 2019 & 30 June 2020 \\
\hline 10 & Italy & Inter & 30 June 2019 & 30 June 2020 \\
\hline 11 & France & Olympique Lyonnais & 30 June 2019 & 30 June 2020 \\
\hline 12 & Germany & Borussia Dortmund & 30 June 2019 & 30 June 2020 \\
\hline
\end{tabular}

Financial analysis techniques were used to evaluate the risks and calculations were made regarding the current ratio, cash ratio, financial leverage ratio, financing ratio, debt / equity ratio and financial risk ratio. In the calculation of the financial risk ratio, equity is divided by the net debt amount obtained by deducting the receivables from the total debt amount. If this ratio is higher than 1 , it is considered as low risk and if it is less than 1 , it is considered as high risk. The high rate of this ratio indicates that the equity is strong and the profits of the previous years also made significant contributions to the business. In addition, although there are various formulas developed to measure the financial risks of businesses, it has been evaluated that this ratio will express the financial risk ratio more accurately in sports clubs. The ratios used and their formulas are given in the table below.

Table 3: Used Ratios and Formulas

\begin{tabular}{|l|l|}
\hline Used ratios & \multicolumn{1}{|c|}{ Formulas } \\
\hline Current rate & Current Assets / Short Term Liabilities \\
\hline Cash rate & Cash and Cash Equivalents / Short Term Liabilities \\
\hline Financial leverage ratio & Total Liabilities / Total Assets \\
\hline Financing rate & Equity / Total Liabilities \\
\hline Debt / equity ratio & Total Liabilities / Equity \\
\hline
\end{tabular}




\subsection{Research results}

As a result of the research, the risks arising from the Covid-19 effect are clearly seen in all the annual financial reports of all clubs that expired in 2020. This effect is reflected in the content of the financial statements as well as being expressed in the additional explanations and footnotes in the financial reports. In this title, the effects in the financial reports of the club due to the Covid-19 pandemic will first be summarized over the amounts reflected in the tables, compared with the previous period, and then the footnote explanations related to the subject will be included. Evaluations on financial structure, reporting and risks will be expressed together in the conclusion section.

\subsubsection{Effects on the structure of financial statements}

Based on the information obtained from the annual financial reports of football clubs in our country that ended on May 31, 2019 and May 31, 2020, the comparison of the financial information of four major football clubs that are open to the public is summarized as follows.

Table 4: Summary of the financial statements of the big four football clubs in Turkey (annual)

\begin{tabular}{|c|c|c|c|c|}
\hline \multicolumn{5}{|c|}{ Beşiktaş (TL) } \\
\hline Account group / items & 31 May 2020 & 31 May 2019 & Difference & $\%$ \\
\hline Cash and cash equivalents & 68.280 & 1.614 .327 & -1.546 .047 & $-95,77$ \\
\hline \begin{tabular}{|l|} 
Current assets \\
\end{tabular} & 1.042 .320 .212 & 765.496.198 & 276.824 .014 & 36,16 \\
\hline Fixed assets & 367.245 .391 & 385.824 .301 & -18.578 .910 & $-4,82$ \\
\hline Short term liabilities & 1.180 .294 .098 & 1.608 .892 .069 & -428.597 .971 & $-26,64$ \\
\hline Long term liabilities & 1.522 .097 .405 & 357.599 .722 & 1.164 .497 .683 & 325,64 \\
\hline Equity & -1.292 .825 .900 & -815.171 .292 & -477.654 .608 & 58,60 \\
\hline Revenues & 497.829 .215 & 621.350 .216 & -123.521 .001 & $-19,88$ \\
\hline Net profit loss & -154.804 .664 & -305.711 .408 & -171.992 .888 & 56,26 \\
\hline Net working capital & -137.973 .886 & -843.395 .871 & & \\
\hline \multicolumn{5}{|c|}{ Fenerbahçe (TL) } \\
\hline Account group / items & 31 May 2020 & 31 May 2019 & Difference & $\%$ \\
\hline Cash and cash equivalents & 13.758 .016 & 7.948 .189 & 5.809 .827 & 73,10 \\
\hline \begin{tabular}{|l|} 
Current assets \\
\end{tabular} & 1.891 .630 .353 & 1.835 .479 .217 & 56.151 .136 & 3,06 \\
\hline Fixed assets & 199.407 .804 & 144.905 .806 & 54.501 .998 & 37,61 \\
\hline Short term liabilities & 1.910 .790 .580 & 1.437.897.012 & 472.893 .568 & 32,89 \\
\hline Long term liabilities & 982.023 .759 & 1.191.179.749 & -209.155 .990 & $-17,56$ \\
\hline Equity & -801.776 .182 & -648.691 .738 & -153.084 .444 & 23,60 \\
\hline Revenues & 544.326 .007 & 707.779 .639 & -163.453 .632 & $-23,09$ \\
\hline Net profit loss & -477.704 .296 & -205.996 .193 & -271.708 .103 & 131,90 \\
\hline
\end{tabular}

PAGE 126| Journal of Corporate Governance, Insurance, and Risk Management | 2021, VOL. 8, Series. 1 


\begin{tabular}{|c|c|c|c|c|}
\hline Net working capital & -19.160 .227 & 397.582.205 & & \\
\hline \multicolumn{5}{|c|}{ Galatasaray (TL) } \\
\hline Account group / items & 31 May 2020 & 31 May 2019 & Difference & $\%$ \\
\hline Cash and cash equivalents & 564,152 & 9.276 .870 & -9.276 .306 & $-99,99$ \\
\hline Current assets & 307.549 .474 & 364.752 .468 & -57.202 .994 & $-15,68$ \\
\hline Fixed assets & 1.486.221.951 & 1.070 .098 .555 & 416.123.396 & 38,89 \\
\hline Short term liabilities & 910.431 .417 & 1.289 .689 .681 & -379.258 .264 & $-29,41$ \\
\hline Long term liabilities & 1.203.104.048 & 417.865.681 & 785.238.367 & 187,92 \\
\hline Equity & -319.697 .459 & -272.671 .217 & -47.026 .242 & 17,25 \\
\hline Revenues & 899.733 .044 & 927.493.705 & -27.760 .661 & $-2,99$ \\
\hline Net profit loss & -46.709 .780 & 24.169 .019 & -70.878 .799 & $-293,26$ \\
\hline Net working capital & -602.881 .943 & -924.937 .213 & & \\
\hline \multicolumn{5}{|c|}{ Trabzonspor (TL) } \\
\hline Account group / items & 31 May 2020 & 31 May 2019 & Difference & $\%$ \\
\hline Cash and cash equivalents & 1.755 .914 & 5.252 .594 & -3.496 .680 & $-66,57$ \\
\hline Current assets & 162.509 .222 & 75.083 .723 & 87.425 .499 & 116,44 \\
\hline Fixed assets & 465.941 .504 & 505.129 .265 & -39.187 .761 & $-7,76$ \\
\hline Short term liabilities & 302.242 .699 & 624.974 .889 & -322.732 .190 & $-51,64$ \\
\hline Long term liabilities & 881.402 .146 & 475.555 .919 & 405.846.227 & 85,34 \\
\hline Equity & -555.194 .119 & -520.317 .820 & -34.876 .299 & 6,70 \\
\hline Revenues & 446.321 .394 & 361.740 .062 & 84.581 .332 & 23,38 \\
\hline Net profit loss & -36.299 .742 & -66.013 .568 & 29.713 .826 & $-45,01$ \\
\hline Net working capital & -139.733 .477 & -549.891 .166 & & \\
\hline
\end{tabular}

Unlike the special accounting period in Turkey, other European football clubs publish their annual financial reports on 30 June 2020. In this context, the summary of the financial information of 8 football clubs, 4 from England and 4 from Europe, which have been published so far and known globally, are as follows:

Table 5: Summary of the financial statements of the 4 football clubs selected from England

\begin{tabular}{|l|c|c|c|c|}
\hline \multicolumn{5}{|c|}{ Manchester United (Sterling) } \\
\hline Account group / items & $\mathbf{3 1}$ June 2020 & $\mathbf{3 1}$ June 2019 & Difference & \% \\
\hline Cash and cash equivalents & 51.539 .000 & 307.637 .000 & -256.098 .000 & $-83,25$ \\
\hline Current assets & 224.806 .000 & 388.323 .000 & -163.517 .000 & $-42,11$ \\
\hline Fixed assets & 1.158 .660 .000 & 1.108 .202 .000 & 50.458 .000 & 4,55 \\
\hline Short term liabilities & 398.344 .000 & 428.844 .000 & -30.500 .000 & $-7,11$ \\
\hline Long term liabilities & 633.890 .000 & 652.479 .000 & -18.589 .000 & $-2,85$ \\
\hline Equity & 351.232 .000 & 415.202 .000 & -63.970 .000 & $-15,41$ \\
\hline Revenues & 509.041 .000 & 627.122 .000 & -118.081 .000 & $-18,83$ \\
\hline Net profit loss & -23.233 .000 & 18.881 .000 & -42.114 .000 & $-223,05$ \\
\hline Net working capital & -173.538 .000 & -40.521 .000 & & \\
\hline \multicolumn{7}{|c|}{ Celtic (Sterling) } & & \% \\
\hline Account group / items & $\mathbf{3 1}$ June 2020 & $\mathbf{3 1 ~ J u n e ~ 2 0 1 9}$ & Difference & $-34,21$ \\
\hline Cash and cash equivalents & 22.406 .000 & 34.057 .000 & -11.651 .000 & -1000 \\
\hline
\end{tabular}




\begin{tabular}{|c|c|c|c|c|}
\hline Current assets & 52.153 .000 & 62.126 .000 & -9.973 .000 & $-16,05$ \\
\hline Fixed assets & 92.107 .000 & 80.935 .000 & 11.172 .000 & 13,80 \\
\hline Short term liabilities & 49.929 .000 & 44.414 .000 & 5.515 .000 & 12,42 \\
\hline Long term liabilities & 12.864 .000 & 16.885 .000 & -4.021 .000 & $-23,81$ \\
\hline Equity & 81.467 .000 & 81.762 .000 & -295.000 & $-0,36$ \\
\hline Revenues & 70.233 .000 & 83.410 .000 & -13.177 .000 & $-15,80$ \\
\hline Net profit loss & -368.000 & 8.738 .000 & -9.106 .000 & $-104,21$ \\
\hline Net working capital & 2.224 .000 & 17.712 .000 & & \\
\hline \multicolumn{5}{|c|}{ Everton (Sterling) } \\
\hline Account group / items & 31 June 2020 & 31 June 2019 & Difference & $\%$ \\
\hline Cash and cash equivalents & 56.404 .000 & 27.429 .000 & 28.975 .000 & 105,64 \\
\hline Current assets & 125.653 .000 & 112.660 .000 & 12.993 .000 & 11,53 \\
\hline Fixed assets & 249.446 .000 & 284.832 .000 & -35.386 .000 & $-12,42$ \\
\hline Short term liabilities & 124.811 .000 & 230.661 .000 & -105.850 .000 & $-45,89$ \\
\hline Long term liabilities & 250.288 .000 & 166.831 .000 & 83.457 .000 & 50,02 \\
\hline Equity & 70.932 .000 & 160.802 .000 & -89.870 .000 & $-55,89$ \\
\hline Revenues & 185.882 .000 & 187.664 .000 & -1.782 .000 & $-0,95$ \\
\hline Net profit loss & -139.869 .000 & -111.815 .000 & -28.054 .000 & 25,09 \\
\hline Net working capital & 842.000 & -118.001 .000 & & \\
\hline \multicolumn{5}{|c|}{ Rangers (Sterling) } \\
\hline Account group / items & 31 June 2020 & 31 June 2019 & Difference & $\%$ \\
\hline Cash and cash equivalents & 11.126 .000 & 1.037 .000 & 10.089 .000 & 972,90 \\
\hline Current assets & 41.038 .000 & 23.860 .000 & 17.178 .000 & 71,99 \\
\hline Fixed assets & 77.748 .000 & 75.230 .000 & 2.518 .000 & 3,35 \\
\hline Short term liabilities & 72.338 .000 & 49.224 .000 & 23.114 .000 & 46,96 \\
\hline Long term liabilities & 14.654 .000 & 16.982 .000 & -2.328 .000 & $-13,71$ \\
\hline Equity & 31.794 .000 & 32.884 .000 & -1.090 .000 & $-3,31$ \\
\hline Revenues & 59.033 .000 & 53.171 .000 & 5.862 .000 & 11,02 \\
\hline Net profit loss & -17.462 .000 & -11.277 .000 & -6.185 .000 & 54,85 \\
\hline Net working capital & -31.300 .000 & -25.364 .000 & & \\
\hline
\end{tabular}

Table 6: Summary of financial statements of $\mathbf{4}$ football clubs selected from Europe

\begin{tabular}{|l|r|r|r|c|}
\hline \multicolumn{7}{|c|}{ Borussia Dortmund (Euro) } \\
\hline Account group / items & 31 June 2020 & \multicolumn{1}{|c|}{ 31 June 2019 } & \multicolumn{1}{c|}{ Difference } & \multicolumn{1}{c|}{$\%$} \\
\hline Cash and cash equivalents & 3.157 .000 & 52.120 .000 & -48.963 .000 & $-93,94$ \\
\hline Current assets & 51.793 .000 & 93.150 .000 & -41.357 .000 & $-44,40$ \\
\hline Fixed assets & 451.466 .000 & 391.754 .000 & 59.712 .000 & 15,24 \\
\hline Short term liabilities & 8.186 .000 & 12.972 .000 & -4.786 .000 & $-36,89$ \\
\hline Long term liabilities & 172.547 .000 & 86.094 .000 & 86.453 .000 & 100,42 \\
\hline Equity & 334.337 .000 & 389.518 .000 & -55.181 .000 & $-14,17$ \\
\hline Revenues & 442.126 .000 & 446.030 .000 & -3.904 .000 & $-0,88$ \\
\hline Net profit loss & -49.662 .000 & 25.844 .000 & -75.506 .000 & $-292,16$ \\
\hline Net working capital & 43.607 .000 & 80.178 .000 & & \\
\hline \multicolumn{7}{|c|}{ Inter (Euro) } \\
\hline Account group / items & $\mathbf{3 1}$ June 2020 & $\mathbf{3 1 ~ J u n e ~ 2 0 1 9}$ & Difference & \% \\
\hline Cash and cash equivalents & 16.898 .000 & 15.664 .000 & 1.234 .000 & 7,88 \\
\hline
\end{tabular}




\begin{tabular}{|c|c|c|c|c|}
\hline Current assets & 107.588 .000 & 130.681 .000 & -23.093 .000 & $-17,67$ \\
\hline Fixed assets & 449.515 .000 & 429.088 .000 & 20.427 .000 & 4,76 \\
\hline Short term liabilities & 99.409 .000 & 53.820 .000 & 45.589 .000 & 84,71 \\
\hline Long term liabilities & 320.376 .000 & 323.619 .000 & -3.243 .000 & $-1,00$ \\
\hline Equity & 137.318 .000 & 182.330 .000 & -45.012 .000 & $-24,69$ \\
\hline Revenues & 85.578 .000 & 144.941 .000 & -59.363 .000 & $-40,96$ \\
\hline Net profit loss & 27.607 .000 & 72.646 .000 & -45.039 .000 & $-62,00$ \\
\hline Net working capital & -212.788 .000 & -192.938 .000 & & \\
\hline \multicolumn{5}{|c|}{ Juventus (Euro) } \\
\hline Account group / items & 31 June 2020 & 31 June 2019 & Difference & $\%$ \\
\hline Cash and cash equivalents & 5.917.079 & 9.744 .722 & -3.827 .643 & $-39,28$ \\
\hline Current assets & 258.319.852 & 165.339 .035 & 92.980 .817 & 56,24 \\
\hline Fixed assets & 910.026 .571 & 751.170 .621 & 158.855 .950 & 21,15 \\
\hline Short term liabilities & 403.604 .924 & 360.215 .100 & 43.389 .824 & 12,05 \\
\hline Long term liabilities & 486.611 .963 & 499.997.934 & -13.385 .971 & $-2,68$ \\
\hline Equity & 239.204.587 & 31.242 .712 & 207.961.875 & 665,63 \\
\hline Revenues & 573.424 .092 & 621.456 .394 & -48.032 .302 & $-7,73$ \\
\hline Net profit loss & -89.682 .106 & -39.895 .794 & -49.786 .312 & 124,79 \\
\hline Net working capital & -145.285 .072 & -194.876 .065 & & \\
\hline \multicolumn{5}{|c|}{ Olympique Lyonnais (Euro) } \\
\hline Account group / items & 31 June 2020 & 31 June 2019 & Difference & $\%$ \\
\hline Cash and cash equivalents & 32.941 .000 & 11.962 .000 & 20.979 .000 & 175,38 \\
\hline Current assets & 111.294 .000 & 103.342 .000 & 7.952 .000 & 7,69 \\
\hline Fixed assets & 591.949 .000 & 526.341 .000 & 65.608 .000 & 12,46 \\
\hline Short term liabilities & 182.746 .000 & 118.829 .000 & 63.917 .000 & 53,79 \\
\hline Long term liabilities & 290.430 .000 & 244.422 .000 & 46.008 .000 & 18,82 \\
\hline Equity & 230.067 .000 & 266.431 .000 & -36.364 .000 & $-13,65$ \\
\hline Revenues & 180.693 .000 & 220.854 .000 & -40.161 .000 & $-18,18$ \\
\hline Net profit loss & -36.606 .000 & 6.404 .000 & -43.010 .000 & $-671,61$ \\
\hline Net working capital & -71.452 .000 & -15.487 .000 & & \\
\hline
\end{tabular}

\subsubsection{Comparative financial analysis results of clubs}

Based on the information obtained from the annual financial reports of football clubs for 2019 and 2020, the comparative financial analysis results of 12 sports clubs are summarized as follows:

Table:7 Comparative financial analysis results of football clubs 


\begin{tabular}{|c|c|c|c|c|c|c|c|c|c|c|c|c|c|}
\hline \multicolumn{14}{|c|}{ Comparative financial analyis results of football clubs } \\
\hline \multirow{2}{*}{ Number } & \multirow{2}{*}{ Football Clubs } & \multicolumn{2}{|c|}{ Current rate } & \multicolumn{2}{|c|}{ Cash rate } & \multicolumn{2}{|c|}{$\begin{array}{c}\text { Financial } \\
\text { leverage ratio }\end{array}$} & \multicolumn{2}{|c|}{ Financing rate } & \multicolumn{2}{|c|}{ Debt / equity ratio } & \multicolumn{2}{|c|}{$\begin{array}{c}\text { Financial risk } \\
\text { ratio }\end{array}$} \\
\hline & & 2019 & 2020 & 2019 & 2020 & 2019 & 2020 & 2019 & 2020 & 2019 & 2020 & 2019 & 2020 \\
\hline 1 & Beşiktaş & 0,4758 & 0,8831 & 0,0010 & 0,0001 & 1,7080 & 1,9172 & $-0,4145$ & $-0,4784$ & $-2,4124$ & $-2,0903$ & $-1,1429$ & $-1,2782$ \\
\hline 2 & Fenerbahçe & 1,2765 & 0,9900 & 0,0055 & 0,0072 & 1,3276 & 1,3834 & $-0,2467$ & $-0,2772$ & $-4,0529$ & $-3,6080$ & $-0,7389$ & $-0,7409$ \\
\hline 3 & Galatasaray & 0,2828 & 0,3378 & 0,0072 & 0,0000 & 1,1901 & 1,1783 & $-0,1597$ & $-0,1513$ & $-6,2623$ & $-6,6110$ & $-0,1912$ & $-0,1657$ \\
\hline 4 & Tnabzonspor & 0,1201 & 0,5377 & 0,0084 & 0,0058 & 1,8968 & 1,8834 & $-0,4728$ & $-0,4691$ & $-2,1151$ & $-2,1319$ & $-0,4987$ & $-0,5350$ \\
\hline 5 & \begin{tabular}{|l|} 
Manchester \\
United
\end{tabular} & 0,9055 & 0,5644 & 0,7174 & 0,1294 & 0,7226 & 0,7461 & 0,3840 & 0,3403 & 2,6043 & 2,9389 & 0,3875 & 0,3553 \\
\hline 6 & \begin{tabular}{|l|} 
Borussia \\
Dortmund
\end{tabular} & 1,0820 & 0,3002 & 0,6054 & 0,0183 & 0,1775 & 0,3429 & 4,5243 & 1,9377 & 0,2210 & 0,5161 & 7,9632 & 2,6329 \\
\hline 7 & Inter & 2,4281 & 1,0823 & 0,2910 & 0,1700 & 0,6743 & 0,7535 & 0,4831 & 0,3271 & 2,0701 & 3,0570 & 0,6924 & 0,4148 \\
\hline 8 & Celtic & 1,3988 & 1,0445 & 0,7668 & 0,4488 & 0,4285 & 0,4353 & 1,3338 & 1,2974 & 0,7497 & 0,7708 & 2,2792 & 2,3741 \\
\hline 9 & Everton & 0,4884 & 1,0067 & 0,1189 & 0,4519 & 0,7120 & 0,8410 & 0,4045 & 0,1891 & 2,4719 & 5,2881 & 0,4786 & 0,2102 \\
\hline 10 & Juventus & 0,4590 & 0,6400 & 0,0271 & 0,0147 & 0,9386 & 0,7619 & 0,0363 & 0,2687 & 27,5332 & 3,7216 & 0,0380 & 0,2956 \\
\hline 11 & Rangers & 0,4847 & 0,5673 & 0,0211 & 0,1538 & 0,6681 & 0,7323 & 0,4967 & 0,3655 & 2,0133 & 2,7361 & 0,7580 & 0,5570 \\
\hline 12 & \begin{tabular}{|l|} 
Olympique \\
Lyonnais
\end{tabular} & 0,8697 & 0,6090 & 0,1007 & 0,1803 & 0,5769 & 0,6728 & 0,7335 & 0,4862 & 1,3634 & 2,0567 & 0,7648 & 0,5054 \\
\hline
\end{tabular}

\subsubsection{Effects of disclosures in financial reports}

Since the Covid-19 effect deeply affects football clubs in Europe, the negative effects seen in the structure and rates of the financial statements are also expressed in financial reports from many angles. Disclosures in the financial reports, future estimates, policies and footnotes on measures taken by the management regarding the significant uncertainty experienced are summarized as follows:

a) Due to the Covid-19 pandemic, social and economic activities were negatively affected and it was decided by the Ministry of Youth and Sports to postpone all leagues as of March 31, 2020. On May 28, 2020, it was announced by the Turkish Football Federation (TFF) that the Super Toto Super League would restart on June 12, and within the scope of preventive measures, the current competitions were postponed and left to the following dates. As a result of these developments, there was a significant decrease in performance-based revenues and these revenues were extended to the next periods. In addition, due to the end of the 2019 and 2020 Spor Toto Super League Cemil Master Season on July 26, 2020, the revenues for the completion degree of the league could not be recorded. In the deferred league, which was completed in July, the revenues of 8 football competitions for performance could not be reflected as income in the financial statements dated May 31, 2020, and were transferred to the next period. 
b) Due to the Covid-19 pandemic, the football club management, professional athletes and technical staff could not be paid in full for the events after the reporting date. Due to Covid-19, the Association of International Football Federations (FIFA) published a circular numbered 1714 on April 07, 2020 and the Turkish Football Federation defined the Covid-19 epidemic as "force majeure" with a similar opinion on April 08, 2020 In this context, it recommended that both parties work together in order to protect the interests of both clubs and athletes, and to postpone the payment or a reasonable reduction in the contract price by mutual agreement. Within the framework of this decision, discussions are ongoing on the issue of discounts on the fees written in the contracts with the athletes included in the assets of the balance sheet of the clubs and their warranty wage obligations. In disputes arising out of disputes or termination of the contract, the trial process is still continuing in the debt lawsuits filed against the club within FIFA.

c) In the financial statements prepared for the principle of continuity of clubs, the increase in period assets slowed down due to Covid-19, but the increase in short-term liabilities accelerated. In this situation, the club's net working capital turned negative and significant uncertainty began to appear in terms of fulfilling short-term liabilities. In addition, when the losses in the equities in the current period and in the previous years are taken in to account, there is a situation of being in debt according to the 376th Article of the Turkish Commercial Code. However, the financial difficulties experienced by the clubs are expected to be overcome with the measures taken by the club management and the breakthroughs that will be made with additional income contributions. Likewise, if the club management's future expectations and cash flow plans are realized, it is considered that these negative effects and important uncertainties will disappear.

d) As of March 23, 2020; the Presidency announced that sports clubs whose cash flows have deteriorated due to Covid-19 will postpone loan principal and interest payments and provide additional financing support. Within the scope of the Economic Stability Shield Package stated in this announcement, negotiations were held with creditor banks and a postponement of interest payments on loans was requested for 6 months. In addition, the club's negotiations with various banks on loan debts and their structuring, and the restructuring request for tax debts are also ongoing.

e) The decrease in club revenues, the deterioration of cash flows, the existence of significant uncertainties regarding the activities and the inability to predict the 
reasonable effects of a second wave that may occur in the Covid-19 pandemic on the financial statements required additional measures to be taken for the effective management of existing resources. In this context, additional decisions were taken to support all kinds of additional income-increasing and resource-generating measures, to keep current expenditures at the optimum level and to strengthen the financial structure. In addition, the wages of the athletes, technical staff wages and the rental fees of the athletes, which are recognized in the "Cost of Sales" account of the income statement for the period, were suspended to the next period due to the extension of the season until June and July, and were deferred and accounted for in accordance with the periodicity principle.

f) The cessation of sports activities caused significant losses in broadcasting rights, sponsorship, naming rights and advertising revenues of the clubs. The effects on the recognition of these losses have the power to affect the activities to be carried out in the future. In this context, these revenues, corresponding to the deferred period, were accounted for in the account of liabilities arising from customer contracts. In addition, assumptions made for financial status and estimates for cash flows continue to be uncertain, together with cyclical developments. Licensed merchandising stores are closed, stadium revenues disappeared, lack of broadcasting revenues, fluctuations in interest and exchange rates negatively affect the borrowing of clubs and bring financial difficulties.

g) Considering the results of the financial analysis, the change in the current ratio and cash ratio is significant compared to the previous year. The significant change in the cash ratio in all selected clubs in our country and abroad reveals the loss of income and the difficulty of cash management experienced during the pandemic process. The fact that the cash ratio approaches 0 (zero) in Beşiktaş and Galatasaray clubs in Turkey also indicates the magnitude of the risk encountered. Although similar decreases are observed in the clubs abroad, the situation of the clubs in our country gives important clues about the sustainability of cash and cash management.

h) During the pandemic period, finding additional funds for clubs to continue their activities and going into borrowing for this has affected the change in leverage ratios. The clubs' need to borrow more and restructuring their debt payments both in Turkey and abroad cause serious changes in financial leverage ratios and financing ratios.

i) Approaching the subject in terms of financial risk ratio, it is accepted that if the equity of the clubs is strong, the ratio will be lower and there will be no problems in fulfilling 
their obligations. The insufficient equity of the clubs in our country and the continuing losses accumulated from the past years increase the financial risk ratio of our country's clubs. In addition, although similar situations are observed in clubs abroad, it is understood from the results that the pandemic increases the risks, causes adverse effects on liquidity and involves significant uncertainties in fulfilling the obligations.

\section{CONCLUSION}

The acceptance of Covid-19 as a pandemic and the subsequent preventive measures have affected the economic life all over the world and left businesses faced with significant uncertainties. Postponement of international organizations and sports competitions, and the cessation of sports activities by regulatory organizations such as FIFA and UEFA caused deterioration in the financial structures and cash flows of football clubs in our country and in Europe. In this context, in the study, the financial statements and independent audit reports of 12 football clubs in our country and in Europe for the period of 2019 and 2020 were examined, the effects of the Covid-19 pandemic were investigated and taken into account in the evaluations.

When looking at the financial structure of the 12 football clubs examined, the risks they face and the effects seen in their reporting, the first thing that stands out is the change in cash and cash equivalents. This effect, especially seen in the current ratio and cash ratio, is important in terms of clearly revealing the problems experienced by the clubs. The amount of cash kept before the pandemic decreased significantly after the pandemic. When we consider the deterioration of cash flows of businesses, even if this situation is accepted as normal, it is certain that the most important issue of the future will be cash management and liquidity. In addition, the decreases in current assets were tried to be compensated by short term borrowings and the net working capital was negatively affected and turned negative. Therefore, the decrease in working capital, which will help clubs in their normal operating cycle, carry out their routine transactions, and manage debt-to-debt relations, will have the power to influence short, medium and long-term decisions in addition to the club's problems in fulfilling its obligations. However, increases in both short-term and long-term borrowing amounts are currently considered as a requirement, but decreases in equity pose a threat to the continuity of the business in the upcoming periods. With the increase in the financing 
ratio and the debt / equity ratio, the borrowing levels have also increased and the financial risks have become more visible. As a matter of fact, this situation has also been expressed in the independent audit reports and it has been especially emphasized in the matters highlighted in the auditor's opinion paragraph.

The decreases in revenues caused by the cessation of sportive and commercial activities have an effect on both revenue and profit / loss for the period. As the revenues of almost all clubs decreased and their contractual liabilities continued, the activities related to the period resulted in a loss. Especially, when we consider the cumulative losses from past years in clubs in our country, the size of the risk faced by the clubs will be better understood. Within the scope of the study, it is a realistic estimation that the effect seen in the annual reports will continue to a great extent, that the decrease in assets and the increase in borrowings will continue, and that the sufficient improvement in revenue and profitability will not be realized in a short time.

Nowadays, where the economic effects of the Covid-19 pandemic are still continuing, the problems experienced by football clubs should be resolved with long-term structural solutions rather than short-term, even if the epidemic is significantly controlled. In this context, ensuring that club activities are transparent and accountable, sharing information with a corporate governance approach, using assets and resources efficiently, and improving the financial situation in accordance with the UEFA Fair Play criteria and ensuring a balanced budget, will minimize the problems that may occur in such cases, It will reduce the degree of risks and contribute to the formation of a sustainable financial structure.

\section{REFERENCES}

AASB. (2020), The impact of coronavirus on financial reporting and the auditor's considerations. New and Alerts, AASB-AUASB JOINT FAQ https://www.aasb.gov.au/admin/file/content102/c3/AASB19009_COVID19_FA.pd f (Date of access: 20/12/2020).

Adana, B., A., Özbirecikli, M. (2020), Bağımsız Denetim Sürecinin Covid-19 Salgınının Etkileri Açısından Değerlendirilmesi, İşletme Araştırmaları Dergisi, 12 (2), 20802093.

Akkaş, J. (2020a), CFO'lar için 10 soru: Covid-19'un işletmeniz üzerindeki etkisinin raporlanmas1. GrantThornton Makaleler. Erişim tarihi: May 7, 2020, https://www.grantthornton.com.tr/en-guncel/makaleler/cfolar-icin-10-sorular (Date of access: 20/12/2020). 
Aksoy, A. ve Tanrı̈ven C. (2007), Sermaye Piyasası Yatırım Araçları ve Analizi, Ankara, Gazi Kitabevi

BDS 570 İşletmenin Sürekliliği Standard1

Bolak, M. (2004), Risk ve Yönetimi, İstanbul, Birsen Yayınevi

Cavlak, H. (2020), “Covid-19 Pandemisinin Finansal Raporlama Üzerindeki Olası Etkileri: BİST 100 Endeksi'ndeki İşletmelerin Ara Dönem Finansal Raporlarının İncelenmesi" Gaziantep Unıversity Journal Of Social Sciences, Special Issue 143168. https://doi.org/10.21547/jss.755865

Dayı, F. (2019), Futbol Kulüplerinde Finansal Risk Analizi, Maliye ve Finans Yazıları, (111), 357-386 . DOI: 10.33203/mfy.493778

Deloitte. (2020), COVID-19'un İşletmelere Olan Finansal Etkileri ve Çözüm Önerileri, https://www2.deloitte.com/tr/tr/pages/financial-advisory/articles/COVID-19-unisletmelere-olan-finansal-etkileri.html (Date of access: 20/12/2020).

Ercan, M.K. and Ban, Ü. (2012), Değere Dayalı İşletme Finansı, Finansal Yönetim, Ankara Gazi Kitabevi

Gough, C. (2020), COVID-19: effect on revenue from sports industry worldwide 2020, https://www.statista.com/statistics/269797/worldwide-revenue-from-sportsmerchandising/ (Date of access:: 20/12/2020).

Göksel, A. G. (2020), Koronavirüs (Covid-19) salgınının spor organizasyonlarına etkisi ve sporda normalleşme süreci. Turkish Studies, 15(4), 451-462. https://dx.doi.org/10.7827/TurkishStudies.44314

ICAEW (2020), Coronavirus, going concern and the auditor's report. Insights. https://www.icaew.com/insights/features/2020/mar-2020/coronavirusgoingconcern-and-the-auditors-report (Date of access: 20/12/2020).

İSMMMO.(2020), Koronavirüsün (Covid-19) Finansal Tablolar ve Bağımsız Denetim Çalışmaları Üzerine Muhtemel Etkileri, İSMMMO Bağımsız Denetim Komitesi, https://archive.ismmmo.org.tr/YAYINLAR/e_kitap/31032020_bulten.pdf (Date of access: 20/1272020).

Koç, M.A. (2020, Covid-19 Salgınının Yarattığı Küresel Kriz Bağlamında Sosyal Medyada Kriz Yönetimi: Türk Hava Yolları Örneği, Avrasya Sosyal ve Ekonomi Araştırmaları Dergisi (ASEAD), C 7, No: 7, pp.190-200, ISSN:2148-9963

Koçak, U.Z., Kaya, D.Ö. (2020), COVID-19 Pandemisi, Spor, Sporcu Üçgeni: Etkilenimler ve Öneriler, İzmir Kâtip Çelebi Üniversitesi Sağlık Bilimleri Fakültesi Dergisi, 5 (2): 129-133

KPMG. (2020), COVID-19 Gündemi, Yeni Gerçeklikte Makro Trendler, https://assets.kpmg/content/dam/kpmg/tr/pdf/2020/04/covid-19-muhasebeseletkileri.pdf (Date of access: 20/12/2020).

KPMG. (2020), Covid-19'un Muhasebesel Etkileri, https://home.kpmg/tr/tr/home/gorusler/2020/07/covid-19-gundemi.html (Date of access: 20/12/2020).

Lange, D. (2020), Potential revenue loss of European football leagues due to the coronavirus, https://www.statista.com/statistics/1105710/potential-revenue-loss-of-majoreurope-football-leaguesdue-to-the-coronavirus-covid-19-bysource/\#statisticContainer (Date of access: 20/12/2020). 
Mazars. (2020), Covid-19: Accounting Implications in Both 2019 \& 2020 Financial Statements, April, France Financial Reporting Advisory Department, https://www.mazars.com/content/download/991808/51848040/version//file/account ing\%201mplications\%20covid-19.pdf (Date of access: 20/12/2020).

Pali, D. and Adiloğlu B. (2020), Kontrol Edilebilen Riskler ve Risk Yönetimi Açıklamaları: Borsa İstanbul Uygulaması, İSMMMO Mali Çözüm Dergisi, 30 (157), 77-102

PWC (2020), Güncel Finansal Raporlama Konularına Kısa Bir Bakış https://www.pwc.com.tr/tr/hizmetlerimiz/denetim/ufrsraporlamasi/bultenler/finansal-raporlama-standarti-tfrs-mayis-haziran-2020.html (Date of access: 20/12/2020).

TFRS 13: Gerçeğe Uygun Değer Ölçümü Standardı

TMS 10: Raporlama Döneminden Sonraki Olaylar Standard1

TMS 8: Muhasebe Politikaları, Muhasebe Tahminlerinde Değişiklikler ve Hatalar Standardı

Türkmen, M. and Özsarı, A. (2020). Covid-19 Salgını ve Spor Sektörüne Etkileri, International Journal of Sport Culture and Science, June, 8(2), Doi:10.14486/IntJSCS.2020.596

Ulun, C. and Yetim A.A. (2016), Türkiye'deki Futbol Kulüplerinin Sportif Başarı Düzeyi ve Mali Yapı Açısından Rasyo (Oran) Analizi İle İncelenmesi: Galatasaray ve Fenerbahçe Örneği, Sportif Bakış: Spor ve Eğitim Bilimleri Dergisi, 3 (1), pp.70-81

Usta, Öcal (2012), İşletme Finansı ve Finansal Yönetim. Ankara: Detay Yayıncılık

Yücel, T.; Mandac1, P.E. and Kurt, G. (2007), İşletmelerin Finansal Risk Yönetimi ve Türev Ürün Kullanımı: İMKB 100 Endeksinde Yer Alan İşletmelerde Bir Uygulama, Muhasebe ve Finansman Dergisi, No:36, October. 